\title{
PENGARUH PROGRAM DIRECT MARKETING TERHADAP CUSTOMER RELATIONSHIP MANAGEMENT PADA FUNCTION ROOM DI HARRIS HOTEL SENTUL CITY BOGOR
}

\author{
Nungky Puspita ${ }^{1 *}$, Hindun Nurhidayati ${ }^{2}$, Fitry Vebria Anggraini $^{3}$ \\ ${ }^{1,2,3}$ Fakultas Pariwisata, Universitas Pancasila Jakarta \\ E-mail: 'nungkypuspita@univpancasila.ac.id \\ *Penulis korespondensi
}

\begin{abstract}
Abstrak
Direct marketing merupakan cara yang efetif untuk menjangkau pelanggan dengan tepat sasaran dan dapat diukur serta dapat membantu mempertahankan pelanggan. Program direct marketing dilakukan oleh sales and marketing department HARRIS Hotel Sentul City Bogor yang memiliki peran yang sangat penting dalam mempromosikan produk yang dimilikinya seperti meningkatkan penjualan function room dengan mempromosikan kepada sasaran pasar. Direct marketing selain dapat menjual function room juga dapat menjalin dan membina hubungan dengan tamu atau biasa disebut customer relationship management. Customer Relationship Management merupakan konsep yang berfokus pada pemeliharaan hubungan dengan pelanggan untuk membangun hubungan jangka panjang dan menguntungkan dengan pelanggan. Tujuan dari penelitian ini untuk mengidentifikasi pengaruh program direct marketing terhadap customer relationship management dalam meningkatkan penjualan function room di HARRIS Hotel Sentul City Bogor. Metode pengumpulan data yang digunakan yaitu observasi, wawancara, kuesioner dan studi kepustakaan. Kuesioner disebarkan secara langsung dengan 100 responden yang memenuhi syarat penelitian. Data yang diperoleh dianalisis dan disajikan secara kuantitatif deskriptif. Teknik analisis data yang digunakan uji validitas, uji reliabilitas serta teknik regresi linear berganda mealui uji koefisien determinan (R2), Uji secara F, Uji T regresi berganda. Hasil temuan penelitian ini menunjukkan bahwa variabel telemarketing, direct mail, kiosk marketing dan the on-line customer berpengaruh signifikan terhadap customer relationship management sedangkan variabel direct selling, dan catalog marketing tidak berpengaruh signifikan terhadap customer relationship management.
\end{abstract}

Kata kunci: Direct marketing; penjualan function room; customer relationship management.

\begin{abstract}
The direct marketing program is carried out by the Sales and Marketing Department of HARRIS Sentul City Bogor Hotel which has a very important role in promoting its products such as increasing sales of function rooms by promoting market targets. Direct marketing, besides being able to sell function rooms, can also establish and foster relationships with guests or commonly called customer relationship management. Customer Relationship Management is a concept that focuses on maintaining relationships with customers to build long-term and profitable relationships with customers. The purpose of this research was to identify the effect of direct marketing programs on customer relationship management in increasing sales of function rooms at HARRIS Sentul City Hotel Bogor. Data collection methods used are observation, interview, questionnaire and literature study. Thisquestionnaires were distributed directly with 100 respondents who met the study requirements. Data analysis techniques used validity test, reliability test and multiple linear regression techniques The findings of this study show that the variables of telemarketing, direct mail, marketing kiosks and the on-line customer have a significant effect on customer relationship management while direct selling, and marketing catalog variables have no significant effect on customer relationship management
\end{abstract}

Keywords: Direct marketing; sales function room; customer relationship manageme

\section{PENDAHULUAN}

Strategi pemasaran memegang peran penting dalam suatu usaha, baik untuk usaha dalam dunia jasa atau manufacture. Adanya promosi yang dilakukan secara berkesinambungan dan terencana diharapkan dapat meningkatkan pendapatan perusahaan dengan kenaikan tingkat penjualan dari produk yang dikeluarkan perusahaan, dalam hal ini adalah hotel. Banyak cara yang dilakukan hotel dalam mempromosikan produknya, salah satunya adalah melakukan direct marketing. Menurut Thop (2002) dalam Gelar 
Maulana (2002) bahwa direct marketing merupakan cara yang efetif untuk menjangkau pelanggan dengan tepat sasaran dan dapat diukur serta dapat membantu mempertahankan pelanggan. Penyataan tersebut menjelaskan bahwa program promosi yang dapat difokuskan langsung kepada tamu bisnis dengan tepat sasaran adalah program direct marketing. Dalam penelitian ini, peneliti memilih HARRIS Hotel Sentul City Bogor sebagai hotel yang melakukan program direct marketing.

Dalam penjualan dan penggunaaan function room tentu memerlukan target pasar. HARRIS Hotel Sentul City Bogor menentukan pasarnya yang berasal dari instansi pemerintahan, perusahaan maupun organisasi lainnya yang banyak menggunakan function room sebagai sarana primer untuk kegiatan penyelenggaraan MICE. MICE berasal dari kepanjangan meeting, incentive, convention, dan exhibition. Menurut Kesrul (2004), MICE sebagai suatu kegiatan kepariwisataan yang aktifitasnya merupakan perpaduan antara leisure dan business, biasanya melibatkan sekelompok orang secara bersama-sama, rangkaian kegiatannya dalam bentuk meetings, incentive travels, conventions, congresses, conference dan exhibition. Kegiatan MICE tentu membutuhkan venue untuk melakukan kegiatan tersebut, untuk itu HARRIS Hotel Sentul City Bogor menyediakan sarana penyelenggaraan MICE seperti function room yang dapat digunakan untuk kegiatan MICE sesuai dengan kebutuhan dari tamu.

Strategi promosi untuk memasarkan function room, HARRIS Hotel Sentul City Bogor melakukan kegiatan diantaranya pada Tabel 1.

Tabel 1. Promosi yang dilakukan HARRIS Hotel Sentul City Bogor

\begin{tabular}{|c|c|c|}
\hline No. Jenis Promosi & Implementasi & Target \\
\hline $\begin{array}{l}\text { 1. Direct } \\
\text { Marketing }\end{array}$ & $\begin{array}{l}\text { Pengiriman } e \text {-mail } \\
\text { blast dan program } \\
\text { Sales Call }\end{array}$ & $\begin{array}{l}\text { Customer } \\
\text { business, } \\
\text { Corporate target }\end{array}$ \\
\hline $\begin{array}{l}\text { 2. Sales } \\
\text { Promotion }\end{array}$ & $\begin{array}{l}\text { Pemberian diskon } \\
\text { pada paket } F \& B \text {, } \\
\text { diskon harga kamar }\end{array}$ & Public \\
\hline 3. Advertising & $\begin{array}{l}\text { Pembuatan } \\
\text { billboard di } 3 \text { titik } \\
\text { toll dan pembuatan } \\
\text { web site }\end{array}$ & Public \\
\hline
\end{tabular}

Sumber: Sales and Marketing Department HARRIS Hotel Sentul City Bogor (diolah oleh penulis), 2018

Tabel 1 menunjukan bahwa ada tiga strategi yang dilakukan oleh HARRIS Hotel Sentul City Bogor, tetapi strategi yang paling mendapat perhatian dari pihak manajemen HARRIS Hotel Sentul City Bogor ialah program direct marketing. Program direct marketing dilakukan oleh Sales and Marketing Department yang sangat berperan dalam mempromosikan produk yang ada, salah satunya adalah function room. Karena target pasar telah ditetapkannya yaitu Customer business dan Corporate target diharapkan akan mempersingkat waktu bagi Sales and Marketing Department dalam melakukan program direct marketing.

Direct marketing selain menjual function room juga dapat menjalin dan membina hubungan dengan tamu atau biasa disebut customer relationship management. Customer Relationship Management merupakan konsep yang berfokus pada pemeliharaan hubungan dengan pelanggan untuk membangun hubungan jangka panjang dan menguntungkan dengan pelanggan (Buttle, 2007). CRM menggambarkan bagaimana perusahaan berinteraksi dan secara aktif mengelola hubungan dengan pelanggan.

Pada dasarnya CRM adalah hubungan dan ikatan jangka panjang antara pemasar atau penyedia jasa dengan pelanggan. Hubungan ini merupakan suatu hubungan yang dituntut untuk saling mempercayai dan ada ketergantungan. Esensi CRM menyangkut hubungan yang terus-menerus dan dituntut untuk saling memiliki kepercayaan dan ketergantungan, sehingga dalam konsep CRM, pemasar sangat menekankan pentingnya hubungan baik jangka panjang dengan pelanggan, yang dapat menciptakan kesadaran dalam bentuk hubungan dan komitmen yang menyeluruh. Stone (2007:121) menyebutkan bahwa ada tiga faktor yang mempengaruhi keberhasilan Customer Relationship Management, yaitu People (SDM), Process (Proses), dan Technology (Teknologi) maka dalam penelitian ini merumuskan bagaimanakah program direct marketing, bagaimanakah customer relationship management dan Bagaimanakah pengaruh program direct marketing terhadap customer relationship management dalam meningkatkan penjualan function room di HARRIS Hotel Sentul City Bogor.

\section{TINJAUAN PUSTAKA}

\section{Pemasaran}

Menurut Kotler (2007) pemasaran mengandung arti kegiatan manusia yang berlangsung dalam hubungannya dengan pasar. Pemasaran dapat didefinikan sebagai kegiatan manusia yang diarahkan untuk memuaskan kebutuhan dan keinginan manusia melalui proses pertukaran, dan inti dari pemasaran adalah seluruh kegiatan yang menyangkut pemuas, meliputi pengembangan produk, pencarian pelanggan, 
komunikasi, distribusi, penetapan harga dan pelayanan. Pemasaran berhubungan dengan mengidentifkasi dan memenuhi kebutuhan manusia dan masyarakat. Salah satu dari definisi pemasaran adalah memenuhi kebutuhan secara menguntungkan.

Pemasaran mempunyai empat unsur pokok kegiatan pemasaran yakni produk, harga, promosi dan distribusi yang dimana satu sama lain saling berkaitan. Sehingga untuk menciptakan pemasaran yang baik dan berhasil dalam mencapai tujuan perusahaan serta memberikan kepuasan terhadap konsumen, maka keempat unsur tersebut harus dirancang sebaik mungkin terutama dengan memperhatikan apa yang diinginkan dan dibutuhkan konsumen sesuai dengan konsep pemasaran.

\section{Pemasaran Langsung (Direct Marketing)}

Menurut Kotler (2007) pemasaran langsung merupakan sebuah aktivitas pemasaran yang dilakukan oleh perusahaan secara langsung kepada konsumennya. Pemasaran langsung adalah penggunaan saluransaluran langsung konsumen untuk menjangkau dan menyerahkan barang dan jasa kepada pelanggan tanpa menggunakan perantara pemasaran seperti surat, telepon, faksimili, e-mail, atau internet untuk berkomunikasi langsung atau meminta tanggapan atau berdialog dengan pelanggan tertentu dan calon pelanggan. Umumnya aktivitas pemasaran ini dilakukan dengan cara mengirimkan direct mail, melakukan telemarketing dan direct selling kepada konsumen yang dituju. Untuk dapat melakukan hubungan secara langsung dengan para konsumen potensialnya maka perusahaan mengelola data based konsumen.

Menurut Warren (2007) pemasaran langsung merupakan sistem pemasaran yang mengintegrasikan unsur-unsur bauran pemasaran yang biasanya terpisah untuk menjual secara langsung, baik kepada konsumen dan bisnis lain dengan menghindari toko pengecer dan penjualan pribadi.

Menurut Kotler dalam Rahmat dan Astri (2017) banyak saluran marketing yang dapat digunakan oleh direct marketing, sebagai berikut:

a. Direct Selling, ini adalah bentuk tertua dari direct marketing, terdapat tenaga penjual professional mendatangi calon konsumen pada lokasi-lokasi tertentu.

b. Direct Mail, ini biasanya menggunakan surat penawaran, pengumuman, juga dikirim audiotape, videotapes, $\mathrm{CD}$, disket, kepada calon-calon konsumen yang sudah dikenal, ini berkembang dengan mengirim fax mail, e-mail, voice mail, pesan-pesan melalui telepon, atau melalui answering machine di rumah-rumah konsumen. c. Catalog Marketing, ini digunakan dalam bentuk pengiriman satu atau beberapa katalog produk kepada alamat terpilih, katalognya bisa berisi seluruh item barang, atau barang khusus, atau bussines catalogs, kadang-kadang berupa $C D$ dan video.

d. Telemarketing Direct Response Marketing, ini dilakukan dengan menggunakan telepon untuk bertujuan menjual langsung dan menarik caloncalon konsumen.

e. Kiosk Marketing, ini adalah usaha penjual menempatkan "customer-order-placing machines" yang ditempatkan ditoko, bandara, dan lokasi lainnya.

f. The On-Line Customer, ini bekerja melalui penggunaan jaringan internet. Konsumen dapat meminta informasi berbagai produk, harganya, fitur dan mutu, dan dapat pula memesan barang sesuai seleranya.

\section{Manajemen Hubungan Pelanggan (Customer Relationship Management)}

Menurut Stone (2007:121), Customer Relationship Management (CRM) adalah: "A business strategy that maximizes profitability, revenue and customer satisfaction by organizing around customer segments, fostering behavior that satisfies customers, and implementing customer-centric processes." Yang artinya sebuah strategi bisnis yang memaksimalkan keuntungan, pendapatan dan pelanggan kepuasan dengan mengorganisir sekitar segmen pelanggan, perilaku membina yang memuaskan pelanggan, dan menerapkan proses customer-centric. Stone (2007: 121) menyebutkan bahwa ada tiga faktor yang mempengaruhi keberhasilan Customer Relationship Management, yaitu People (SDM), Process (Proses), dan Technology (Teknologi). People (Sumber Daya Manusia) dalam hal ini adalah karyawan sebagai pelaksana CRM. SDM merupakan faktor yang terpenting dalam kesuksesan CRM. (Stone, 2007). Lalu, Process (Proses) merupakan prosedur yang membantu untuk menjalin hubungan dengan pelanggan (Stone, 2007). Sedangkan, Technology (teknologi) merupakan alat penunjang dalam melengkapi CRM (Stone, 2007).

Menurut Buttle (2007) CRM adalah strategi bisnis inti yang mengkolaborasikan proses serta fungsi internal, jaringan eksternal demi menciptakan dan menyampaikan nilai-nilai kepada pelanggan dengan tujuan untuk mendapatkan keuntungan. Sehingga dapat disimpulkan bahwa pengertian customer relationship management merupakan sebuah proses dan strategi pemasaran jangka panjang dalam mengelola informasi pelanggan secara detail, yang dilakukan 
oleh perusahaan dalam memaksimalkan loyalitas pelanggan melalui penciptaan dan pewujudan nilai para pelanggan sasaran secara profitable.

\section{Akomodasi Perhotelan}

Pengertian hotel menurut Hotel Proprietors Act, 1956 dalam Agus Sulastiyono (2006:1) Hotel adalah suatu perusahaan yang dikelola oleh pemiliknya dengan menyediakan pelayanan makanan, minuman dan fasilitas kamar untuk tidur kepada orang-orang yang sedang melakukan perjalanan dan mampu membayar dengan jumlah yang wajar sesuai dengan pelayanan yang diterima tanpa adanya perjanjian khusus.

Menurut Wiyasha (2010:5) Hotel merupakan usaha yang mencari laba sebagai hasil akhir aktivitas bisnisnya. Pengklasifikasian hotel menurut Wiyasha (2010:5) bertujuan untuk menciptakan persaingan bisinis yang sehat, memberikan panduan bagi tamu tentang harga dan fasilitas serta layanan yang diberikan oleh hotel pada klasifikasi tertentu, memberikan panduan bagi para pemilik modal jika hendak berbisnis pada satu klasifikasi hotel. Lanjutnya, Wiyasha (2010: 19) mengemukakan pendapatan hotel bersumber dari penjualan kamar, makanan, minuman dan pendapatan lain (minor operated department sales) seperti telepon, laundry, dry cleaning, kolam renang dan sebagainya. Adapun biaya-biaya dan harga pokok terjadi untuk biaya bahan dipakai habis disetiap bagian hotel, harga pokok makanan dan minuman, biaya administrasi dan umum, biaya pemasaran, biaya bunga, biaya depresiasi dan amortisasi, biaya sumber daya manusia, biaya pemeliharaan sarana fisik hotel, biaya energi dan laba/rugi yang dihasilkan.

\section{Function Room}

Function room adalah suatu ruangan yang digunakan untuk melakukan kegiatan penyelenggaraan rapat (meeting), bonus perjalanan (incentive), pertemuan (convention), pameran (exhibition), dan tujuan tertentu. Function Room dalam persiapannya sangat memerlukan manajemen yang baik karena dalam menyelenggarakan suatu kegiatan, tamu bukan mebutuhkan ruangan rapat saja tetapi tamu juga memerlukan kebutuhan lainnya seperti makanan, tempat tidur, tour dan kenangan yang saling terkait. pengaturan manajemen yang baik akan menghasilkan pendapatan yang memuaskan bagi hotel yang membentuk kesan, nama baik hotel di mata tamu.

Menurut Tjiptono dan Gregorious (2011) Fasilitas adalah sumber daya fisik yang ada sebelum suatu jasa dapat ditawarkan kepada konsumen, lebih lanjut mengenai fasilitas menurut Kotler (2000) mendefinisikan fasilitas yaitu segala sesuatu yang bersifat sumber daya fisik dan disediakan oleh pihak penjual jasa untuk mendukung kenyamanan konsumen. Konsumen dalam melakukan pembelian terhadap suatu jasa banquet, tentunya akan memperhatikan fasilitas function room dari jasa banquet yang ditawarkan. Jadi, dengan adanya perbedaan fasilitas function room dari suatu hotel jasa banquet dengan hotel yang lainnya, konsumen tentunya akan tertarik dengan fasilitas yang sudah lengkap dan nyaman. Maka konsumen akan melakukan pembelian jasa banquet atau sebaliknya.

\section{Kerangka Pemikiran}

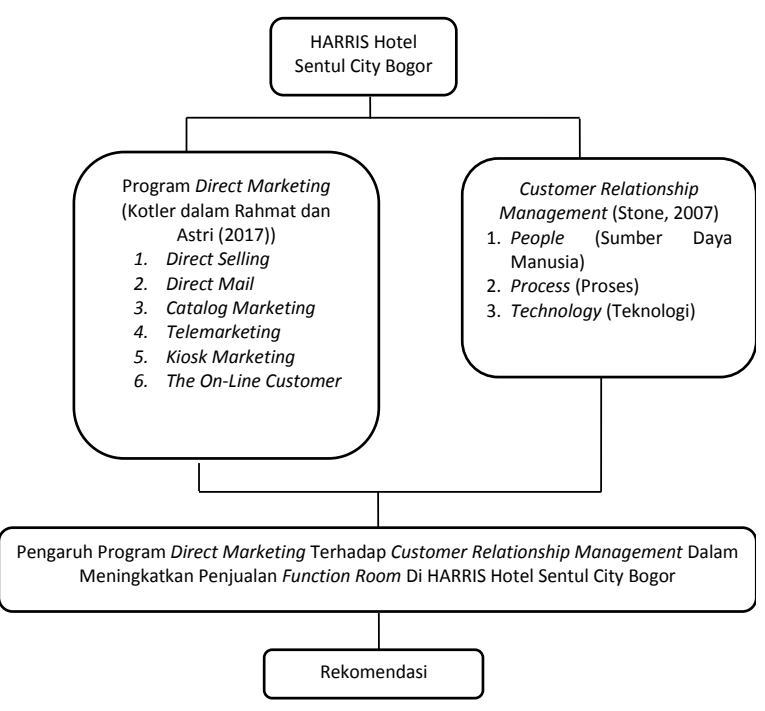

Gambar 1. Kerangka Pemikiran

\section{Hipotesis}

Menurut Kriyantono (2006) hipotesis merupakan pendapat atau penyataan yang masih belum tentu kebenarannya, yang masih diuji dahulu dan karenanya bersifat sementara atau dugaan awal.

Hipotesis dalam penelitian ini dirumuskan sebagai berikut:

1. Direct Selling

Menurut Kotler dalam Rahmat dan Astri (2017) direct selling merupakan bentuk tertua dari direct marketing, terdapat tenaga penjual professional mendatangi calon konsumen pada lokasi-lokasi tertentu.

$\mathrm{Ha}_{1}$ : terdapat pengaruh program direct selling terhadap customer relationship management dalam meningkatkan penjualan function room di HARRIS Hotel Sentul City Bogor.

$\mathrm{Ho}_{1}$ : tidak terdapat pengaruh program direct selling terhadap customer relationship management dalam meningkatkan penjualan function room di HARRIS Hotel Sentul City Bogor. 


\section{Direct Mail}

Menurut Kotler dalam Rahmat dan Astri (2017) direct mail biasanya menggunakan surat penawaran, pengumuman, juga dikirim audio-tape, videotapes, $\mathrm{CD}$, disket, kepada calon-calon konsumen yang sudah dikenal, ini berkembang dengan mengirim fax mail, e-mail, voice mail, pesan-pesan melalui telepon, atau melalui answering machine di rumah-rumah konsumen.

$\mathrm{Ha}_{2}$ : terdapat pengaruh program direct mail terhadap customer relationship management dalam meningkatkan penjualan function room di HARRIS Hotel Sentul City Bogor.

$\mathrm{Ho}_{2}$ : tidak terdapat pengaruh program direct mail terhadap customer relationship management dalam meningkatkan penjualan function room di HARRIS Hotel Sentul City Bogor.

3. Catalog Marketing

Menurut Kotler dalam Rahmat dan Astri (2017) catalog marketing ini digunakan dalam bentuk pengiriman satu atau beberapa katalog produk kepada alamat terpilih, katalognya bisa berisi seluruh item barang, atau barang khusus, atau bussines catalogs, kadang-kadang berupa $C D$ dan video.

$\mathrm{Ha}_{3}$ : terdapat pengaruh program catalog marketing terhadap customer relationship management dalam meningkatkan penjualan function room di HARRIS Hotel Sentul City Bogor.

$\mathrm{Ho}_{3}$ : tidak terdapat pengaruh program catalog marketing terhadap customer relationship management dalam meningkatkan penjualan function room di HARRIS Hotel Sentul City Bogor.

\section{Telemarketing}

Menurut Kotler dalam Rahmat dan Astri (2017) telemarketing ini dilakukan dengan menggunakan telepon untuk bertujuan menjual langsung dan menarik calon-calon konsumen.

Ha: terdapat pengaruh program telemarketing terhadap customer relationship management dalam meningkatkan penjualan function room di HARRIS Hotel Sentul City Bogor.

Ho4: tidak terdapat pengaruh program telemarketing terhadap customer relationship management dalam meningkatkan penjualan function room di HARRIS Hotel Sentul City Bogor.

\section{Kiosk Marketing}

Menurut Kotler dalam Rahmat dan Astri (2017) kiosk marketing yaitu usaha penjual menempatkan "customer-order-placing machines" yang ditempatkan ditoko, bandara, dan lokasi lainnya.
Has: terdapat pengaruh program kiosk marketing terhadap customer relationship management dalam meningkatkan penjualan function room di HARRIS Hotel Sentul City Bogor.

Hos: tidak terdapat pengaruh program kiosk marketing terhadap customer relationship management dalam meningkatkan penjualan function room di HARRIS Hotel Sentul City Bogor.

\section{The On-Line Customer}

Menurut Kotler dalam Rahmat dan Astri (2017) the on-line customer, ini bekerja melalui penggunaan jaringan internet. Konsumen dapat minta informasi berbagai produk, harganya, fitur dan mutu, dan dapat pula memesan barang sesuai seleranya.

$\mathrm{Ha}_{6}$ : terdapat pengaruh program the on-line customer terhadap customer relationship management dalam meningkatkan penjualan function room di HARRIS Hotel Sentul City Bogor.

Ho6: tidak terdapat pengaruh program the on-line customer terhadap customer relationship management dalam meningkatkan penjualan function room di HARRIS Hotel Sentul City Bogor.

\section{METODE PENELITIAN}

Penelitian ini menggambarkan pengaruh program direct marketing terhadap customer relationship management dalam meningkatkan penjualan function room di HARRIS Hotel Sentul City Bogor. Penelitian ini menggunakan metode kuantitatif deskriptif, yaitu hasil penelitiannya yang kemudian diolah dan dianalisis untuk diambil kesimpulannya, artinya penelitian yang menekankan analisisnya pada data-data yang bersifat numeric (angka). Dengan menggunakan metode penelitian ini, akan diketahui hubungan yang signifikan antara variabel yang diteliti, sehingga menghasilkan kesimpulan yang akan mendeskripsikan gambaran mengenai objek yang diteliti (Sugiyono, 2012).

\section{Uji Validitas}

Sugiyono (2012) Uji Validitas merupakan suatu langkah pengujian yang dilakukan terhadap isi (content) dari suatu instrument. Uji validitas dilakukan untuk membuktikan bahwa alat yang dibuat untuk mengukur adalah benar-benar mengukur apa yang ingin diukur. Pengujian dilakukan dengan mencari korelasi dari setiap indikator terhadap skor totalnya. Validitas bertujuan untuk menguji instrument yang dipilih. Uji validitas data menggunakan konsistensi 
internal (internal consistency) dengan program SPSS. Pendekatan yang dilakukan adalah menghubungankan suatu construct. Dimana suatu indikator dipandang "valid" sepanjang sesuai dengan telaah.

\section{Uji Reliabilitas}

Menurut Sugiyono (2012) reliabilitas berkenaan dengan derajat, konsistensi dan stabilitas data atau temuan. Reliabilitas adalah indeks yang menunjukan sejauh mana suatu alat pengukur dipercaya atau dapat diandalkan. Bila suatu alat ukur dipakai dua kali untuk mengukur gejala yang sama dan hasil pengukuran yang diperoleh relatif konsisten, maka alat ukur tersebut reliabel. Dengan kata lain, reliabilitas menunjukan konsistensi suatu alat ukur di dalam mengukur gejala yang sama. Suatu kuesioner dianggap reliable apabila jawaban dari pertanyaannya konsisten. Dalam program SPSS, terdapat fasilitas perhitungan pengukuran reliabilitas melalui uji statistik Cronbach Alpha ( $\alpha$ ). Cronbach's Alpha adalah koefisien reliabilitas yang menunjukan bagaimana bagian-bagian dari suatu set berkorelasi secara positif satu sama lainnya (Sekaran (2003) dalam Nabilah Ufairah (2017)). Suatu instrumen dapat dianggap reliable jika memiliki koefisien alpha $(\alpha)$ sebesar 0,6 atau lebih.

\section{Teknik Penentuan Responden}

Pemilihan sampel dengan metode yang tepat dapat menggambarkan kondisi populasi sesungguhnya yang akurat, dan dapat menghemat biaya penelitian secara efektif. Sampel menurut Furchan (2004) adalah sebagian atau wakil populasi yang diteliti. Sedangkan menurut Sugiyono (2001) sampel adalah sebagian dari jumlah dan karakteristik yang dimiliki oleh populasi. Dalam pengambilan ukuran sampel pada penelitian ini yaitu menggunakan teknik non-probability melalui purposive sampling. sampel yaitu berdasarkan adanya hubungan kerjasama antara tamu potensial berasal dari instansi pemerintahan, perusahaan maupun organisasi lainnya dengan pihak HARRIS Hotel Sentul City Bogor. Lalu, tamu yang sudah merasakan dan menggunakan function room, maupun tamu yang baru menggunakan function room di HARRIS Hotel Sentul City Bogor. Untuk menentukan ukuran responden/ sampel mengacu pada rumus Slovin. Peneliti mengambil jumlah populasi dari jumlah pax pada tahun 2017 sebesar 123,000 pax, yaitu sebagai berikut:

$$
\begin{gathered}
n=\frac{N}{1+N e^{2}} \\
n=\frac{123,000}{1+\left(123,000.0,1^{2}\right)} \longrightarrow n=\frac{123,000}{1,231}=99,9
\end{gathered}
$$

Jadi berdasarkan rumus diatas, sampel yang diambil sebanyak 99,9 orang. Untuk memudahkan perhitungan, maka dibulatkan menjadi 100 orang untuk mewakili populasi dalam penelitian ini.

\section{Metode Analisis Data}

Pada penelitian ini mengenai pengaruh program direct marketing terhadap customer relationship management dalam meningkatkan penjualan function room ini akan diolah dan dianalisa menggunakan analisis regresi berganda dengan bantuan pengolah data software IBM SPSS statistic (Statistica Package for Special Science). SPSS adalah suatu software yang berfungsi untuk menganalisis data, melakukan perhitungan statistik baik parametrik maupun non parametrik (Ghozali, 2001). Menurut Supardi dalam Nabilah Ufairah (2017) uji regresi berganda dilakukan untuk menunjukan besarnya pengaruh beberapa variabel bebas terhadap variabel terkait.

Analisis regresi linear berganda merupakan regresi yang memiliki satu variabel dependen $(\mathrm{Y})$ dan dua atau lebih variabel independen $\left(X_{1}, X_{2}, X_{3}, \ldots X n\right)$. Analisis ini untuk mengetahui arah hubungan antara variabel independen dengan variabel dependen apakah masing-masing variabel independen berhubungan postif atau negatif, lalu untuk memprediksi nilai dari variabel dependen apabila nilai variabel independen mengalami kenakan atau penurunan. Pengujian hipotesis dengan analisa regresi linear berganda gabungan dari uji lainnya seperti uji koefisien determinasi $\left(\mathrm{R}^{2}\right)$, uji $\mathrm{f}$ dan uji t.

\section{HASIL PENELITIAN DAN PEMBAHASAN}

\section{Uji Koefisien Determinan $\left(\mathbf{R}^{2}\right)$}

Koefisien determinan (Nilai R square) berguna untuk mengukur kemampuan model dalam menerangkan variabel dependent. Nilai $\mathrm{R}^{2}$ berkisar antara $0-1$. Semakin mendekati 1 maka berati semakin besar variabel independen mampu menjelaskan variabel dependen. Untuk mengetahui besar kontribusi variabel bebas direct marketing (X) dan variabel terikat customer relationship management $(\mathrm{Y})$ digunakan nilai $R^{2}$. Hasil perhitungan koefisien determinan disajikan pada tabel 2 .

Tabel 2. Hasil Uji Koefisien Determinan $\left(\mathrm{R}^{2}\right)$

Model Summary

\begin{tabular}{|l|r|r|r|r|}
\hline Model & \multicolumn{1}{|c|}{$\mathrm{R}$} & R Square & $\begin{array}{c}\text { Adjusted } \\
\text { R Square }\end{array}$ & $\begin{array}{r}\text { Std. Error of } \\
\text { the Estimate }\end{array}$ \\
\hline 1 & $.889^{\mathrm{a}}$ & .790 & .776 & 1.27392 \\
\hline
\end{tabular}

a. Predictors: (Constant), theonlinecustomer, kioskmarketing, telemarketing, directselling, catalogmarketing, directmail 
Berdasarkan tabel 2 dijelaskan bahwa nilai dari koefisien determinan $\left(\mathrm{R}^{2}\right)$ adalah 0.790 atau $79 \%$. Berdasarkan hasil perhitungan koefisien determinan $\left(\mathrm{R}^{2}\right)$, maka selanjutnya dapat diambil kesimpulan bahwa variabel direct marketing (X) memiliki pengaruh yang cukup sebesar 79\% terhadap customer relationship management di HARRIS Hotel Sentul City Bogor sedangkan sisanya $21 \%$ dipengaruhi oleh faktor-faktor lain diluar variabel $\mathrm{X}$ yang tidak diteliti oleh penulis.

\section{Uji F (Test Simultan)}

Pengujian F dilakukan untuk mengetahui apakah hasil dari analisis regresi yang dilakukan terhadap variabel bebas $(\mathrm{X})$ secara bersama-sama berpengaruh signifikan atau variabel terikat $(\mathrm{Y})$. Uji $\mathrm{F}$ dapat dilakukan dengan membandingkan $\mathrm{F}_{\text {Hitung }}>$ dari $\mathrm{F}_{\text {tabel }}$ atau signifikan kurang dari 0.05 maka Ho ditolak dan sebaliknya, jika $F_{\text {hitung }}<$ dari $F_{\text {tabel }}$ atau signifikan lebih dari 0,05 maka Ho diterima. Penelitian dengan analisa regresi ini digunakan untuk mengitung besarnya pengaruh antara variabel bebas yaitu direct marketing (X) terhadap variabel terikat (Y) yaitu customer relationship management. Tujuan dari uji $\mathrm{F}$ adalah untuk model kelayakan. Hasil pengujian hipotesis secara simultan dengan menggunakan SPSS 15.0 dapat dilihat table 3 .

Tabel 3. Hasil Uji F Secara Simultan

ANOVAp

\begin{tabular}{|c|c|c|c|c|c|c|}
\hline Model & & $\begin{array}{l}\text { Sum of } \\
\text { Squares }\end{array}$ & $d f$ & Mean Square & $\mathrm{F}$ & Sig. \\
\hline & Regression & 566.072 & 6 & 94.345 & 58.135 & $.000^{\mathrm{a}}$ \\
\hline & Residual & 150.928 & 93 & 1.623 & & \\
\hline & Total & 717.000 & 99 & & & \\
\hline
\end{tabular}

a. Predictors: (Constant), theonlinecustomer, kioskmarketing, telemarketing, directselling, catalogmarketing, directmail

b. Dependent Variable: $\mathrm{crm}$

Berdasarkan tabel 3 menunjukkan hasil pengujian uji $F$ untuk menguji pengaruh secara bersama sama memiliki estimasi $\mathrm{F}$ sebesar 58.135 dengan nilai signifikan sebesar 0,000 (sangat kecil) lebih kecil dari 0,05 maka dapat dinyatakan Ho ditolak dan $\mathrm{Ha}$ diterima. Hal ini berarti bahwa secara keseluruhan variabel independen dalam penelitian ini yaitu direct marketing (X) secara bersama-sama berpengaruh secara simultan yang dapat digunakan terhadap customer relationship management di HARRIS Hotel Sentul City Bogor. Hal tersebut menunjukkan bahwa program direct marketing sangat berkontribusi positif terhadap customer relationship management $\mathrm{di}$ HARRIS Hotel Sentul City Bogor.

\section{Uji T Test (Parsial)}

Uji T digunakan untuk mengetahui apakah masing-masing variabel bebas secara parsial mempunyai pengaruh yang signifikan terhadap variabel terikat. Dapat juga dikatakan jika $t_{\text {hitung }}>t_{\text {tabel }}$ atau $-t_{\text {hitung }}<t_{\text {tabel }}$ maka hasilnya signifikan dan berarti Ho ditolak dan Ha diterima. Sedangkan jika $t_{\text {hitung }}<t$ tabel atau $-t_{\text {hitung }}>\mathrm{t}_{\text {tabel }}$ maka hasilnya tidak signifikan dan berarti Ho diterima dan Ha ditolak. Hasil dari uji T dapat dilihat tabel 4.3 dijelaskan pada tabel sebagai berikut:

Berdasarkan hasil analisis data dengan menggunakan teknik regresi berganda dengan melihat nilai siginifikan yang mengukur pengaruh program direct marketing terhadap customer relationship management dapat diinterpretasikan sebagai berikut:

\section{Direct Selling}

Tabel 4. Hasil Direct Selling

\begin{tabular}{llll}
\hline \multicolumn{1}{c}{ Hipotesis } & $\begin{array}{c}\text { Hasil Pengujian } \\
\text { Hipotesis }\end{array}$ & Nilai Sig & Keterangan \\
\hline X1 & Variabel Direct & 0.656 & Tidak \\
Direct & Selling tidak & & berpengaruh Ho \\
Selling & berpengaruh & diterima, Ha \\
& signifikan & ditolak \\
& terhadap & \\
& customer & \\
& relationship & \\
& management. & \\
\hline
\end{tabular}

Berdasarkan hasil pengolahan data melalui pengujian hipotesa dalam table 4 ditemukan hasil bahwa variabel direct selling (X1) direct marketing memiliki nilai koefisien regresi sebesar -0.062 dengan nilai signifikan sebesar 0.656 lebih besar dari tingkat signifikasi $(<0.05)$ maka $\mathrm{Ho}_{1}$ diterima, $\mathrm{Ha}_{1}$ ditolak. Dengan demikian dapat dinyatakan bahwa variabel direct selling (X1) direct marketing tidak berpengaruh signifikan customer relationship management. Hal tersebut sesuai dengan teori yang dikemukakan oleh Kotler dalam Rahmat dan Astri (2017) bahwa direct selling adalah bentuk tertua dari direct marketing, terdapat tenaga penjual professional mendatangi calon konsumen pada lokasi-lokasi tertentu dan juga merupakan salah satu media untuk memasarkan suatu produk atau jasa yang menggunakan sales untuk menarik para tamu, dengan memasarkan secara langsung calon konsumen/tamu juga dapat merasakan pelayanan yang prima dari sales yang secara langsung dapat mempermudah pemesanan sesuai kebutuhan yang diinginkan oleh calon konsumen/tamu dengan bermusyawarah bersama pihak sales \& marketing HARRIS Hotel Sentul City Bogor. 
Direct selling tidak berpengaruh signifikan terhadap customer relationship management, hal tersebut dikarenakan direct selling adalah program yang dilakukan sales untuk mempresentasikan mengenai informasi produk hotel secara individu dan bertatap muka langsung artinya direct selling terdiri atas sales sebagai pemberi informasi dan PIC yang terdiri dari 1 sampai 3 orang sebagai penerima informasi. Artinya, saat direct selling berlangsung sales hanya menemui pihak calon tamu yang bertanggung jawab atau yang disebut PIC (Person in Charge). Jika calon tamu sedang menggunakan function room di HARRIS Hotel Sentul City Bogor maka tamu lainnya tidak menangani langsung kebutuhannya, semua akan ditangani oleh PIC yang dibantu langsung oleh pihak sales. Untuk itu ketika tamu membutuhkan bantuan maka tamu tersebut meminta bantuan kepada PIC tersebut. Dan PIC akan meneruskan kepada sales yang menangani grup untuk menggunakan function room. Jadi dalam pelaksanaannya sales hanya berhubungan langsung dengan pihak PIC dan tidak mengikutsertakan pihak lain.

\section{Telemarketing}

Tabel 5. Hasil Telemarketing

\begin{tabular}{llll}
\hline \multicolumn{1}{c}{ Hipotesis } & $\begin{array}{c}\text { Hasil Pengujian } \\
\text { Hipotesis }\end{array}$ & Nilai Sig Keterangan \\
\hline X2 & Variabel & 0.043 & Berpengaruh \\
Telemarketing & Telemarketing & & Ha diterima, \\
& berpengaruh & & Ho ditolak \\
& signifikan terhadap & & \\
& customer & & \\
& relationship & & \\
& management. & \\
\end{tabular}

Berdasarkan hasil pengolahan data melalui pengujian hipotesa dalam table 5 ditemukan hasil bahwa variabel telemarketing (X2) direct marketing memiliki nilai koefisien regresi sebesar 0.326 dengan nilai signifikan sebesar 0.043 lebih kecil dari tingkat signifikasi $(<0.05)$ maka $\mathrm{Ha}_{2}$ diterima, $\mathrm{Ho}_{2}$ ditolak. Maka dapat dinyatakan bahwa variabel telemarketing (X2) direct marketing berpengaruh signifikan customer relationship management. Sehingga sesuai dengan teori yang dikemukakan oleh Kotler dalam Rahmat dan Astri (2017) bahwa telemarketing dilakukan dengan menggunakan telepon untuk bertujuan menjual langsung dan menarik calon-calon konsumen. Penggunaan media telepon untuk menarik calon tamu baru ataupun tamu yang sudah ada, dan juga menyediakan layanan dengan menerima pesanan dan menjawab pertanyaan yang diajukan oleh tamu guna memenuhi kebutuhan tamu dan meningkatkan efektivitas biaya.
Telemarketing berpengaruh signifikan terhadap customer relationship management, hal ini dikarenakan telemarketing merupakan bentuk komunikasi verbal dengan media telepon sebagai alat untuk melakukan pemasaran. Penilaian tersebut diukur berdasarkan kesopanan, keramahan, ketepatan waktu menelepon dan kejelasan informasi yang disampaikan melalui telepon yang mampu menarik minat tamu untuk menggunakan function room di HARRIS Hotel Sentul City Bogor. Para tamu yang potensial akan meminta informasi secara langsung dengan pihak sales mengenai produk hotel. Telemarketing berlangsung saat sales memberikan informasi yang diinginkan oleh tamu. Telemarketing dilakukan oleh siapapun tamu yang ingin bertanya mengenai harga dan produk hotel, tanpa dibatasi.

\section{Direct Mail}

Tabel 6. Hasil Direct Mail

\begin{tabular}{llll}
\hline Hipotesis & $\begin{array}{c}\text { Hasil Pengujian } \\
\text { Hipotesis }\end{array}$ & Nilai Sig & Keterangan \\
\hline X3 & Variabel Direct Mail & 0.000 & Berpengaruh \\
Direct & berpengaruh & & Ha diterima, \\
Mail & signifikan terhadap & Ho ditolak \\
& customer & & \\
& relationship & & \\
& management. & & \\
\hline
\end{tabular}

Berdasarkan hasil pengolahan data melalui pengujian hipotesa dalam table 6 ditemukan hasil bahwa variabel direct maill (X3) direct marketing memiliki nilai koefisien regresi sebesar 0.982 dengan nilai signifikan sebesar 0.000 lebih kecil dari tingkat signifikasi $(<0.05)$ maka $\mathrm{Ha}_{3}$ diterima, $\mathrm{Ho}_{3}$ ditolak. Dengan demikian dapat dinyatakan bahwa variabel direct mail (X3) direct marketing berpengaruh signifikan customer relationship management. Hal tersebut sesuai dengan teori yang dikemukakan oleh Kotler dalam Rahmat dan Astri (2017) bahwa direct mail biasanya menggunakan surat penawaran, pengumuman, juga dikirim audio-tape, videotapes, $\mathrm{CD}$, disket, kepada calon-calon konsumen yang sudah dikenal, ini berkembang dengan mengirim fax mail, email, voice mail, pesan-pesan melalui telepon, atau melalui answering machine di rumah-rumah konsumen. Direct mail juga merupakan bentuk komunikasi yang dirancang untuk mencapai sasaran kelompok tamu potensial melalui media email atau surat elektronik dengan tujuan menimbulkan kesadaran atau tindakan dari tamu tersebut. Surat penawaran yang dikirimkan untuk calon tamu berupa kelengkapan mengenai informasi produk hotel yang dikemas dengan menarik serta informatif agar pesan dapat 
diterima oleh pembacanya dan dapat menarik minat tamu untuk membeli produk tersebut melalui e-mail.

Direct mail berpengaruh signifikan terhadap customer relationship management, hal ini dikarenakan setiap tahunnya, HARRIS Hotel Sentul City Bogor memperbaharui harga produk yang telah direncanakan yang terdiri dari harga kamar maupun harga untuk penggunaan function room. Dengan adanya database, mempermudah sales untuk melakukan promosi melalui pengiriman email blast dalam menawarkan produk hotel kepada target-target pasar seperti government, dan corporate. Direct mail memanfaatkan email sebagai platform utama, maka program direct mail dapat mengurangi anggaran promosi dari HARRIS Hotel Sentul City Bogor. Selain itu, direct mail diharapkan dapat menarik tamu untuk membaca surat penawaran tersebut dengan upaya mendorong minat tamu untuk menggunakan function room di HARRIS Hotel Sentul City Bogor. Hal lainnya, direct mail secara berkala dan berkesinambungan akan menciptakan hubungan antara calon tamu/konsumen dengan hotel.

\section{Catalog Marketing}

Tabel 7. Hasil Catalog Marketing

\begin{tabular}{llll}
\hline Hipotesis & $\begin{array}{l}\text { Hasil Pengujian } \\
\text { Hipotesis }\end{array}$ & Nilai Sig & Keterangan \\
\hline X4 & Variabel Catalog & 0.131 & Tidak \\
Catalog & Marketing tidak & & berpengaruh Ho \\
Marketing & diterima, Ha \\
& berpengaruh & & ditolak \\
& signifikan terhadap & & \\
& customer & & \\
& relationship & & \\
& management. & \\
\hline
\end{tabular}

Berdasarkan hasil pengolahan data melalui pengujian hipotesa dalam table 7 ditemukan hasil bahwa variabel catalog marketing (X4) direct marketing memiliki nilai koefisien regresi sebesar 0.292 dengan nilai signifikan sebesar 0.131 lebih besar dari tingkat signifikasi $(<0.05) \mathrm{maka} \mathrm{Ho}_{4}$ diterima, $\mathrm{Ha}_{4}$ ditolak. Dengan demikian dapat dinyatakan bahwa variabel catalog marketing (X4) direct marketing tidak berpengaruh signifikan customer relationship management. Hal tersebut sesuai dengan teori yang dikemukakan oleh Kotler dalam Rahmat dan Astri (2017) bahwa catalog marketing digunakan dalam bentuk pengiriman satu atau beberapa katalog produk kepada alamat terpilih, katalognya bisa berisi seluruh item barang, atau barang khusus, atau bussines catalogs.

Catalog marketing tidak berpengaruh signifikan terhadap customer relationship management, hal ini dikarenakan saat ini di era globalisasi hotel/perusahaan dalam memasarkan produknya tidak jarang menggunakan program ini dengan mengirimkan katalogkatalog. Katalog biasanya berisi mengenai itemitem/komoditas yang dijual dengan menampilkan foto produk disertai dengan harga dan deskripsi singkat mengenai produk tersebut. HARRIS Hotel Sentul City Bogor masih menggunakan program ini dalam memasarkan produk. Pemasaran katalog dilakukan melalui penyebaran katalog oleh hotel kepada calon tamu atau tamu, baik di luar hotel maupun di dalam hotel. Contoh penyebaran katalog di luar hotel yaitu pengiriman katalog, hanya dilakukan kepada tamu yang loyal dalam penggunaan function room di HARRIS Hotel Sentul City Bogor. Hal ini akan memicu terjadi hubungan baik jangka panjang dengan tamu. Pada kenyataannya, saat ini banyak tamu yang tidak menyukai membaca katalog melalui bentuk cetak, banyak tamu lebih tertarik membaca dalam bentuk non-cetak karena lebih memudahkan pembaca. Hal tersebut, tidak akan mengurungkan minat tamu untuk membaca katalog dalam bentuk cetakan.

Penyebaran katalog di dalam hotel yaitu HARRIS Hotel Sentul City Bogor menyediakan katalog yang diupayakan dapat membantu tamu untuk mengetahui produk-produk yang dijual, namun katalog ini masih dalam bentuk cetakan yang berada di counter front desk agent. Saat peneliti melakukan observasi, katalog dalam bentuk cetakan sama sekali tidak dibaca atau tidak dilihat oleh tamu, tamu lebih memilih membaca katalog yang berada dalam bentuk televisi atau bentuk non-cetak. Hal tersebut tidak efisien, karena katalog dalam bentuk cetak akan membuang-buang anggaran promosi. Dapat disimpulkan, tamu akan lebih tertarik kepada katalog yang bersifat non-cetak.

\section{Kiosk Marketing}

Tabel 8. Hasil Kiosk Marketing

\begin{tabular}{|c|c|c|c|}
\hline Hipotesis & $\begin{array}{l}\text { Hasil Pengujian } \\
\text { Hipotesis }\end{array}$ & Nilai Sig & Keterangan \\
\hline $\begin{array}{l}\text { X5 } \\
\text { Kiosk } \\
\text { Marketing }\end{array}$ & $\begin{array}{l}\text { Variabel Kiosk } \\
\text { Marketing } \\
\text { berpengaruh } \\
\text { signifikan terhadap } \\
\text { customer } \\
\text { relationship } \\
\text { management. }\end{array}$ & 0.048 & $\begin{array}{l}\text { Berpengaruh Ha } \\
\text { diterima, Ho } \\
\text { ditolak }\end{array}$ \\
\hline
\end{tabular}

Berdasarkan hasil pengolahan data melalui pengujian hipotesa dalam table 8 ditemukan hasil bahwa variabel kiosk marketing (X5) direct marketing memiliki nilai koefisien regresi sebesar 
0.287 dengan nilai signifikan sebesar 0.048 lebih kecil dari tingkat signifikasi $(<0.05)$ maka $\mathrm{Ha}_{5}$ diterima, $\mathrm{Ho}_{5}$ ditolak. Dengan demikian dapat dinyatakan bahwa variabel kiosk marketing (X5) direct marketing berpengaruh signifikan customer relationship management. Hal tersebut sesuai dengan teori yang dikemukakan oleh Kotler dalam Rahmat dan Astri (2017) bahwa kiosk marketing adalah usaha penjual menempatkan "customer-order-placing machines" atau "mesin penerima pesanan pelanggan" yang ditempatkan ditoko, bandara, dan lokasi lainnya.

Kiosk marketing berpengaruh signifikan terhadap customer relationship management, hal ini dikarenakan calon tamu mamupun tamu yang akan melakukan pembelian produk hotel menginginkan lokasi atau tempat dapat membuat nyaman tamu. Sehingga tamu merasa senang dan bersinambung dengan pelayanan yang memuaskan. HARRIS Hotel Sentul City Bogor memberikan kenyamanan bagi tamu saat berada di hotel, contohnya tersedia lobby yang bersih, fasilitas yang memadai. Dalam program kiosk marketing, lokasi pemberian informasi yang dapat dijangkau oleh tamu merupakan hal utama dari keberhasilan program ini. Apabila tamu telah merasa loyal dengan pemenuhan kebutuhan fasilitas yang nyaman, maka tamu dengan pihak hotel dapat menjalin hubungan jangka panjang yang berdampak pada peningkatan penggunaan function room di HARRIS Hotel Sentul City Bogor.

\section{The On-Line Customer}

Tabel 9. Hasil The On-Line Customer

\begin{tabular}{llcl}
\hline Hipotesis & $\begin{array}{l}\text { Hasil Pengujian } \\
\text { Hipotesis }\end{array}$ & $\begin{array}{c}\text { Nilai } \\
\text { Sig }\end{array}$ & Keterangan \\
\hline $\mathrm{X} 6$ & Variabel The & 0.000 & Berpengaruh \\
The On- & On-Line & & Ha diterima, \\
Line & $\begin{array}{l}\text { Customer } \\
\text { bustomer }\end{array}$ & & Ho ditolak \\
& berpengaruh & & \\
& signifikan & & \\
& terhadap & & \\
& customer & & \\
& relationship & & \\
& management. & & \\
\hline
\end{tabular}

Berdasarkan hasil pengolahan data melalui pengujian hipotesa diatas ditemukan hasil bahwa variabel the on-line customer (X6) direct marketing memiliki nilai koefisien regresi sebesar 0.866 dengan nilai signifikan sebesar 0.000 lebih kecil dari tingkat signifikasi $(<0.05)$ maka $\mathrm{Ha}_{6}$ diterima, $\mathrm{Ho}_{6}$ ditolak. Dengan demikian dapat dinyatakan bahwa variabel the on-line customer (X6) direct marketing berpengaruh signifikan customer relationship management. Hal tersebut sesuai dengan teori yang dikemukakan oleh Kotler dalam Rahmat dan Astri (2017) bahwa the online customer bekerja melalui penggunaan jaringan internet. Konsumen dapat meminta informasi berbagai produk, harganya, fitur dan mutu, dan dapat pula memesan barang sesuai seleranya. Tujuan dari pemasaran melalui internet adalah untuk memasarkan, mempromosikan, membangun, dan mempertahankan customer relationship melalui bentuk aktivitas online. Daya tarik situs, kesesuaian informasi dengan kenyataan, kelengkapan informasi, kemudahan mengakses informasi menjadi nilai lebih agar memberikan kemudahan tamu dalam proses pemesanan.

The on-line customer berpengaruh signifikan terhadap customer relationship management, hal ini dikarenakan saat ini internet tidak dapat dipisahkan dari kegiatan pemasaran. Pemasaran melalui online atau internet, guna memperoleh setumpuk informasi komparatif tentang produk yang dijual. Tamu memusatkan perhatian pada kriteria objektif seperti harga, kualitas produk, dan ketersediaan. HARRIS Hotel Sentul City Bogor memiliki media online dalam menjangkau target pasarnya, seperti website, instagram dan facebook yang dijalankan secara aktif. Media online merupakan sarana promosi hotel yang diupayakan dapat mendatangkan calon tamu potensial. Disamping itu, program pemasaran ini dapat menghemat waktu calon tamu/tamu dalam melakukan proses pemesanan. Melalui program ini yang nantinya akan ditindaklanjuti dengan pertemuan antara sales dan calon tamu. Hal tersebut, akan memicu adanya hubungan baik jangka panjang antara tamu dengan sales maupun dengan hotel.

\section{SIMPULAN DAN SARAN}

Berdasarkan hasil penelitian yang telah dilakukan dengan menggunakan analisis kuantitatif deskriptif serta menggunakan analisis regresi berganda antara pengaruh program direct marketing terhadap customer relationship management dalam meningkatkan penjualan function room di HARRIS Hotel Sentul City Bogor, maka dapat ditarik kesimpulan bahwa secara keseluruhan, tamu HARRIS Hotel Sentul City Bogor pada penelitian ini memberikan nilai yang baik terhadap direct marketing. Direct marketing yang dilakukan oleh HARRIS Hotel Sentul City Bogor melalui direct selling, telemarketing, direct mail, catalog marketing, kiosk marketing dan the on-line customer. Penilaian tertinggi tamu terhadap direct marketing HARRIS Hotel Sentul City Bogor ada pada sub variabel telemarketing, direct mail, kiosk marketing dan the on-line customer dan penilaian terendah yaitu pada sub variabel direct selling dan catalog 
marketing. Hal ini disebabkan karena tanggapan yang baik tamu terhadap pihak hotel muncul dari persepsi tamu yang merasakan cara penyampaian informasi produk yang ada di HARRIS Hotel Sentul City Bogor oleh sales \& marketng team terutama pada saat presentasi melalui media-media seperti telepon, email, tempat lokasi yang nyaman, dan media online/internet untuk memudahkan tamu dan dapat menghemat waktu. Hal tersebut dapat memunculkan persepsi yang baik serta mendorong minat dan ketertarikan tamu dalam menggunakan function room di HARRIS Hotel Sentul City Bogor.

Secara keseluruhan, customer relationship management di HARRIS Hotel Sentul City Bogor berada pada kategori penilaian tinggi, hal ini mengindikasikan bahwa tamu memberikan penilaian baik dalam membangun hubungan baik antar tamu dengan pihak hotel yang akan memberikan nilai positif dalam menggunakan function room di HARRIS Hotel Sentul City Bogor. Hubungan terjadi karena indikator people, process, dan technology bekerja secara bersamaan. Sumber daya manusia yang dapat membantu dan menangani kebutuhan, keinginan, bahkan masalah tamu, SDM dapat menyelesaikan dengan baik. Pada proses pemesanan function room yang cepat, agar memberikan kemudahan tamu, dan penggunaan media atau teknologi yang dimanfaatkan sebagai akses tamu dalam menjangkau produk dari HARRIS Hotel Sentul City Bogor.

\section{Implikasi Hasil Penelitian}

1. Pelaksanaan direct marketing mempunyai pengaruh terhadap customer relationship management dalam meningkatkan penjualan function room di HARRIS Hotel Sentul City Bogor. Oleh karena itu, secara keseluruhan hotel harus lebih meningkatkan program direct marketing sebagai suatu strategi pemasaran, meningkatkan kesadaran tamu akan produk dan pelayanan, meningkatkan jumlah pembelian produk dan menguatkan kesan merek di benak tamu HARRIS Hotel Sentul City Bogor bahwa HARRIS Hotel Sentul City Bogor merupakan hotel yang dapat memberikan kepuasan pelayanan bagi tamu yang menggunakan function room.

2. HARRIS Hotel Sentul City Bogor hendaknya dimulai dari dalam manajemen HARRIS Hotel Sentul City Bogor terlebih dahulu. Untuk meningkatkan kualitas soft skill dan hard skill staff, sudah semestinya pihak manajemen mengadakan pelatihan sumber daya manusia (SDM) untuk lebih mengasah kemampuan staff dalam penguasaan product knowledge agar saat mempresentasikan dapat tersampaikan dengan jelas dan mudah dipahami oleh tamu, lal $u$ hotelier attitude dalam menangani tamu, dan menegaskan pentingnya koordinasi antar departemen dalam menangani kebutuhan tamu selama menggunakan function room di HARRIS Hotel Sentul City Bogor.

\section{Saran dan Keterbatasan}

Penelitian ini hanya fokus pada satu sample hotel yaitu HARRIS Hotel Sentul City Bogor. Diharapkan penelitian selanjutnya mengambil sample dan obyek penelitian dari industri hotel bintang 3 atau 4 atau 5 agar dapat melihat tren Direct Marketing dan Customer Relationship Management pada Function Room. Selain itu dari tren Industri tersebut diharapkan dapat menganalisa kualitas soft skill dan hard skill staff pada umumnya.

\section{DAFTAR REFERENSI}

Barnes, J. (2003). Secrets of Customer Relationship Management (Rahasia Manajemen Pelanggan). Yogyakarta (ID): Andi Offset.

Buttle, Francis. (2007). Customer Relationship Management: Concept, And Tools (Manajemen Hubungan Pelanggan). Jakarta (ID): Bayumedia Publishing.

Gelar Maulana F. (2012). Pengaruh Program Direct Marketing Terhadap Keputusan Menggunakan Meeting Package Di Golden Flower Hotel Bandung [Skripsi]. Bandung (ID): Universitas Pendidikan Indonesia.

Kesrul, M. (2004). Meeting, Incentive Trip, Conference, Exhibition. Graha Ilmu.

Kotler, Philip. (2000. Manajemen Pemasaran. Jakarta (ID): PT Prehallindo.

Kotler, Philip. (2007). Manajemen Pemasaran, Analisis Perencanaan, Pengendalian. Edisi Bahasa Indonesia. Jakarta (ID): Salemba Empat.

Rahmat Saputra dan Astri Wulandari. (2017). Penerapan Direct Marketing Dan Personal Selling Pada Produk Indihome (Studi Kasus Di PT. Telekomunikasi Indonesia, Tbk Kandatel Cijaura Bandung Pada Tahun 2017 [Jurnal]. Bandung (ID): Universitas Telkom.

Stone, Bob dan Jacobs. (2007). Successful Direct Marketing Metods. McGraw Hill. New York (US).

Sugiyono. (2012). Metode Penelitian Kuantitatif, Kualitatif Dan R\&D. Bandung (ID): Alfabeta.

Sulastiyono, Agus. (2006). Manajemen Penyelenggaraan Hotel: Manajemen Usaha Jasa Pariwisata Dan Akomodasi. Bandung (ID): Alfabeta.

Tjiptono, Fandy dan Gregorius, Chandra. (2011). Service, Quality \& Statifaction. Yogyakarta. (ID): Andi Offset. 
Utama IGBR, Mahadewi EMN. (2012). Metodologi Penelitian Pariwisata \& Perhotelan. Yogyakarta (ID): Andi Offset.
Warren, Carl S. Duchac. Jonathan E. (2007). Principles of Accounting. Prentice Hall. 